\title{
Production of xylanase by Fusarium oxysporum using agro- industrial waste
}

Utilização de resíduos agroindustriais para a produção de xilanase por Fusarium oxysporum

\author{
L. T. A. de Bastos*; R. D. Batista; A. C. M. Lima; I. L. dos Santos; F. C. de \\ Paula-Elias; C. C. A. A. Santos; A. F. de Almeida \\ Programa de Pós-Graduação em Ciência e Tecnologia de Alimentos, Universidade Federal do Tocantins, \\ 77001-090, Palmas-Tocantins, Brasil \\ *bastoslunara@gmail.com \\ (Trabalho avaliado e selecionado pela Comissão do III CTOCTA)
}

\begin{abstract}
This study aimed to optimize the production of xylanase, under submerged conditions using Fusarium oxysporum. Firstly, it was carried out the selection of the best source of carbon from agricultural waste, such as soybean husk, cassava peel, pineapple crown, corn straw, rice husk, bacaba, barley bagasse and, corncob. They were milled and sieved with a maximum granulation of $1 \mathrm{~mm}$. The cultures were carried out by 132 hours $30^{\circ} \mathrm{C}$ and $180 \mathrm{rpm}$. Among the agroindustrial residues, corn straw was the one that stood out with a greater enzymatic activity of $12.6 \mathrm{U} / \mathrm{mL}$. In the second step, it was used Plackett-Burman design to screen the nutrients sources important to xylanase production. Thus, independent variables significant were urea and $\mathrm{MgSO}_{4}$. These variables selected by Plackett-Burman were then used in a Central Composite Rotational Design present activity of $26.6 \mathrm{U} / \mathrm{mL}$ and the predicted was $34.5 \mathrm{U} / \mathrm{mL}$. So, the xylanase production by $F$. oxysporum can be optimize using corn straw, a low-cost waste found in large quantities. Keyword: xylanase, agroindustrial waste, enzymatic activity.
\end{abstract}

O objetivo deste trabalho foi otimizar a produção de xilanase, sob condições submersas, utilizando o fungo Fusarium oxysporum. Na primeira etapa, foi realizada a seleção da melhor fonte de carbono a partir de resíduos agrícolas, sendo eles tegumento de soja, casca de mandioca, coroa de abacaxi, palha de milho, casca de arroz, bacaba, bagaço de cevada e sabugo de milho. Os mesmos foram moídos e peneirados com granulação máxima de $1 \mathrm{~mm}$. Os cultivos foram realizados por 132 horas, $30^{\circ} \mathrm{C}$ e $180 \mathrm{rpm}$. Dentre esses resíduos, a palha de milho foi a que se destacou apresentando uma maior atividade enzimática igual a 12,57 $\mathrm{U} / \mathrm{mL}$. Na etapa seguinte foi usado o delineamento Plackett-Burman para rastrear as fontes de nutrientes importantes do meio para produção de xilanase. Dessa forma, as variáveis independentes significativas a ureia e o $\mathrm{MgSO}_{4}$. Essas variáveis selecionadas pelo Plackett-Burman foram então utilizadas em um Delineamento Composto Central Rotacional e a melhor atividade enzimática foi igual a 26/60 U/mL e a predita igual a $34.5 \mathrm{U} / \mathrm{mL}$. Assim, a produção de xilanase por $F$. oxysporum pode ser otimizada utilizando palha de milho como fonte de carbono, sendo um resíduo de baixo custo, consequentemente de mais fácil acesso.

Palavras-chave: xilanase, resíduos agroindustriais, atividade enzimática.

\section{INTRODUCTION}

Plant cell walls are composed of polysaccharides, lignins, proteins that together form a complex structure composed of different arrangements and interconnections forming a polysaccharide block, these arrangements and the interconnections of structural polysaccharides inside the cell walls are very restricted to enzyme access, explaining why these glycan compounds are recalcitrant to biological degradation [1].

Cellulose is the most challenging material to degrade and deconstruct into carbohydrate monomers. Hemicellulose is the second-largest component of the plant wall after cellulose. It comprises a group of heterogeneous polysaccharides, representing $20-35 \%$ of the total dry weight of the biomass, consisting essentially of a large fraction of xylan with a linear $\beta-(1-4)$-D-xylose skeleton [2,3]. The enzymatic hydrolysis of these lignocellulosic materials by cellulolytic and hemicellulolytic enzymes is the most promising approach to obtain high yields of products vital for economic success. For its complete degradation, hemicellulose mainly requires the enzymes endo-1,4- $\beta$-xylanase (EC 3.2.1.8) and 1,4- $\beta$-xylosidase (EC 3.2.1.37), where the first enzyme acts 
in the chain $\beta(1,4)$ D-xylopyranose bond homopolymer for the production of xylooligomers and the second enzyme acts on these xylooligomers to release xylose. Importantly, xylanases (EC 3.2.1.8) belong to the glycoside hydrolases (GH) group (EC 3.2.1.-), based on their amino acid sequences (CAZy database) and are part of the GH families 5, 7, 8, 9, 10, 11, 12, 16, 26, 30, 43, 44, 51 and 62 [3]. In addition to their importance in the cycling of nutrients in nature, xylanases are widely used commercially in processes of bioconversion of lignocellulosic material or agroindustrial residues, biobleaching in the paper industry, improvement of bread texture and volume, clarification of juice and wine, improvement of the nutritional value of animal feedstock, extraction of vegetable oil, coffee and starch [4].

Fusarium oxysporum is a saprophytic soil fungus and can infect and cause disease in a plant host, due to the fungus penetrating the vascular system and degrading its cell walls. Another feature of this fungus is that it can convert cellulose and hemicellulose into ethanol, from the enzymes it produces. In addition, $F$. oxysporum can produce alkaline xylanase, widely used in the paper and biofuel industries, as well as acidic xylanase applied in juice clarification and production of xylo-oligosaccharides that can be used in pharmaceutical products [5, 6].

The production of xylanases is normally carried out by solid state fermentation (FES) and submerged fermentation (FSm) processes. FSm represents more than $90 \%$ of industrial enzyme production due to the ease of control during the aerobic fermentation process, ensuring greater availability of nutrients, oxygen supply, and less fermentation time when compared to other techniques $[3,7]$. However, the high cost of producing these enzymes makes their application difficult because the purified xylan substrate is extremely expensive, and an alternative to reduce the cost is the use of low-cost agricultural residues that are normally incorporated into the soil after harvesting, or are destined for animal feed, which can be used as carbon and nitrogen sources in the formulation of fermentation media [8]. Statistical analysis of the medium formulation helps to minimize the number of unused components at the end of fermentation, evaluating the effect of various components on enzyme production [3]. This study aimed to evaluate the production of xylanase by $F$. oxysporum in different residual agro-industrial biomass (soybean husk, cassava husk, pineapple crown, corn straw, rice husk, bacaba, barley bagasse, and corn cob) and estimate the number of enzymes produced from the best chemical composition of the culture medium under submerged conditions.

\section{MATERIAL AND METHODS}

\subsection{Microorganism}

The strain of $F$. oxysporum isolated from decaying pequi fruits [9], was maintained in malt extract agar medium, at $4{ }^{\circ} \mathrm{C}$, by Castellani method [10], at the Laboratory of Food Biotechnology and Purification of Bioproducts, University Campus of Gurupi, Federal University of Tocantins/TO. The stock culture was maintained on Vogel salts agar medium [11], containing wheat bran. The peals were performed periodically, in inclined tubes and petri dishes, kept at 30 ${ }^{\circ} \mathrm{C}$ for 7 days and later used or stored at $4{ }^{\circ} \mathrm{C}$.

The conidia of the Fusarium oxysporum strain, stored in the LABAP-UFT, which were subcultured in slant tubes, were suspended at a concentration of $10^{6} \mathrm{spores} / \mathrm{mL}$ in sterile saline $(\mathrm{NaCl}) 0.85 \%$. One millilitre of this suspension was used to inoculate the liquid culture media.

\subsection{Selection of carbon source for Xylanase production}

Submerged cultures were carried out in $125 \mathrm{~mL}$ Erlenmeyers containing $20 \mathrm{~mL}$ of supplementary basal medium proposed by Mandels and Weber (1969) [12], composed of: $\mathrm{KH}_{2} \mathrm{PO}_{4} 2.0 \mathrm{~g} / \mathrm{L} ;\left(\mathrm{NH}_{4}\right)_{2} \mathrm{SO}_{4} 1.4 \mathrm{~g} / \mathrm{L} ;$ Urea $0.3 \mathrm{~g} / \mathrm{L} ; \mathrm{CaCl}_{2} .2 \mathrm{H}_{2} \mathrm{O} 0.3 \mathrm{~g} / \mathrm{L} ; \mathrm{MgSO}_{4} .7 \mathrm{H}_{2} \mathrm{O} 0.3 \mathrm{~g} / \mathrm{L}$; $\mathrm{FeSO}_{4} .7 \mathrm{H}_{2} \mathrm{O} 5.0 \mathrm{mg} / \mathrm{L} ; \mathrm{MnSO}_{4} . \mathrm{H}_{2} \mathrm{O} 1.6 \mathrm{mg} / \mathrm{L} ; \mathrm{ZnSO}_{4} .7 \mathrm{H}_{2} \mathrm{O} 1.4 \mathrm{mg} / \mathrm{L} ; \mathrm{CoCl}_{2} 2.0 \mathrm{mg} / \mathrm{L} ;$ Yeast extract $1.0 \mathrm{~g} / \mathrm{L}$; Peptone $1.0 \mathrm{~g} / \mathrm{L}$ and $1 \%$ of vegetable biomass as a carbon source from different types of agricultural residues. The vegetal biomasses used were soybean husk, cassava husk, 
pineapple crown, corn straw, rice husk, bacaba, barley bagasse, and corn cob. These were previously ground in knife mills and sieved with a maximum granulation of $1 \mathrm{~mm}$. The cultures were carried out in three repetitions and incubated for 132 hours, $30^{\circ} \mathrm{C}$, and $180 \mathrm{rpm}$. After the incubation period, the fermented broth was separated from the biomass by filtration on filter paper with the aid of a Buchner funnel, kitassate and vacuum pump and then the fermented broth was used for activity analysis enzymatic.

\subsection{Xylanolytic activity}

The xylanolytic activity followed the Miller method (1959) [13], where it was determined from a $1 \%(\mathrm{w} / \mathrm{v})$ xylan solution in McIlvaine 5.5 buffer. $0.4 \mathrm{~mL}$ of the solution was added to the test tubes. The tubes were kept for $5 \mathrm{~min}$ in a water bath at $50{ }^{\circ} \mathrm{C}$. Test tubes containing $0.2 \mathrm{~mL}$ of 3,5-dinitrosalicylic acid (DNS) solution were prepared. $0.4 \mathrm{~mL}$ of the appropriately diluted enzymatic extract was added, this way the reaction was started, and $0.2 \mathrm{~mL}$ samples were removed at time intervals of $0 \mathrm{~min}$ and $5 \mathrm{~min}$, adding immediately to the DNS solution. After completion of the reaction, the DNS was heated to $100{ }^{\circ} \mathrm{C}$ for $5 \mathrm{~min}$. Waited to cool down and $2.0 \mathrm{~mL}$ of distilled water was added, and then the determination of reducing sugars was carried out, using xylose as a standard. Readings were taken in duplicates and read at an absorbance to $540 \mathrm{~nm}$. Where a unit is defined as the amount of enzyme releasing $1 \mu \mathrm{mol}$ of xylose per milliliter per minute of reaction. Enzyme activity is calculated with the following equation:

$$
A=\frac{A b s}{\varepsilon} \cdot \frac{1}{V_{i}} \cdot 10^{3} \cdot V_{f} \cdot \frac{1}{t} \cdot \text { diluição }
$$

Onde, $\varepsilon=$ molar extinction coefficient $\left(M^{-1} \cdot \mathrm{cm}^{-1}\right)$

$$
\begin{aligned}
& \text { Abs }=\text { absorbance } \\
& V_{i}=\text { initial volume } \\
& V_{f}=\text { final volume } \\
& t(\mathrm{~min})=\text { reaction time in minutes }
\end{aligned}
$$

\subsection{Fermentation parameters}

Yield $\left(\mathrm{U} \cdot \mathrm{g}^{-1}\right)$ and productivity $\left(\mathrm{U} \cdot \mathrm{g}^{-1} \cdot \mathrm{h}^{-1}\right)$ were calculated with the following equations respectively:

$$
\begin{gathered}
\gamma_{p / s}=\frac{P_{F}-P_{0}}{S_{0}} \\
P_{P}=\frac{\text { Xilanase }}{t}
\end{gathered}
$$

Onde, $P_{F}=x y$ lanase at the end of cultivation

$P_{0}=x y l a n a s e$ at the beginning of cultivation

$S_{0}=$ substrate

$t=$ time in hours

\subsection{Experimental planning}

\subsubsection{Placktt \& Burman}

The Plackett \& Burman experimental design was used with 12 trials and three central points, with 15 runs, at three coded levels $(-1 ; 0 ;+1)$ to select the significant variables. Multivariate experiments using appropriate statistical models will explain their effect on the fermentation 
process [14]. The independent variables tested were: $\mathrm{KH}_{2} \mathrm{PO}_{4}$ concentration; $\left(\mathrm{NH}_{4}\right)_{2} \mathrm{SO}_{4}$; Urea; $\mathrm{MgSO}_{4} .7 \mathrm{H}_{2} \mathrm{O} ; \mathrm{CaCl}_{2}$; meat peptone; yeast extract and Tween-80, presented in Table 2, which shows the coded variables and actual values.

The experiment was carried out in random order and the answers were used to adjust the linear and/or quadratic model and consequently the response surface. All results were evaluated at a significance level of $5 \%$.

\subsubsection{Composite central rotational design}

Central Composite Rotational Design (CCRD), for two factors with 5 repetitions at the central point and axial points, was used in this investigation with a significance level of $5 \%$. The variables used were Urea and $\mathrm{MgSO}_{4} .7 \mathrm{H}_{2} 0$ and each in five coded levels $(-1.41 ;-1 ; 0 ;+1 ;+1.41)$, as shown in Table 3 [15].

\subsection{Analysis of results}

The results of the experimental planning were analyzed using STATISTICA software version 10 , whose values were submitted to analysis of variance (ANAVA). Results were expressed as means of 3 independent experiments followed by standard deviation. The Scott-Knott test was applied to the averages, with a 5\% significance level using the ASSISTAT computer system. The results were presented in the form of graphs and tables.

\section{RESULTS AND DISCUSSION}

\subsection{Selection of the best carbon source for xylanase production}

F. oxysporum was cultivated on different carbon sources under submerged conditions to verify the production of xylanase. The carbon sources used were soybean tegument, cassava husk, pineapple crown, corn straw, rice straw, bacaba, barley bagasse and corn cob (Table 1). The highest xylanase production $(\mathrm{p}<0.05)$ was obtained in the medium containing corn straw $(12.57$ $\mathrm{U} / \mathrm{mL}$ ), with a yield equal to $1306.94 \mathrm{U} \cdot \mathrm{g}^{-1}$ and productivity equal to $2.0 \mathrm{U}^{\mathrm{g}} \mathrm{g}^{-1} \cdot \mathrm{h}^{-1}$. Similar results were described by Pritsch et al. (2020) [16] using the Penicillium crustosum where it obtained a production of $25.45 \mathrm{U} / \mathrm{mL}$ and $19.35 \mathrm{U} / \mathrm{mL}$ in stationary and agitated culture conditions, respectively, showing that this carbon source is great for enzyme production. This fact can be explained by the fact that corn straw is a residue composed of a high concentration of hemicellulose $(58 \%)$ and cellulose (41\%) inducing the production of xylanase [17]. In addition to these substrates described above and used in the work, other agro-industrial residues, such as wheat bran [3] and sugarcane bagasse [18] are also potential sources for the xylanase production.

Table 1 - Xylanase production by Fusarium oxysporum using different agro-industrial residues as a carbon source.

\begin{tabular}{cccc}
\hline & \multicolumn{3}{c}{ Xylanase activity } \\
\cline { 2 - 4 } Carbon source & $\mathbf{U} / \mathbf{m L}$ & $\boldsymbol{Y}_{\mathbf{p} / \mathrm{s}}$ & $\boldsymbol{P}_{\mathbf{p}}$ \\
\hline Soybean Integument & $0.96^{\mathrm{d}}$ & $64.02^{\mathrm{d}}$ & $0.10^{\mathrm{d}}$ \\
Rice husk & $0.05^{\mathrm{d}}$ & $31.50^{\mathrm{d}}$ & $0.05^{\mathrm{d}}$ \\
Bacaba & $0.40^{\mathrm{d}}$ & $43.27^{\mathrm{d}}$ & $0.07^{\mathrm{d}}$ \\
Cassava husk & $0.18^{\mathrm{d}}$ & $17.96^{\mathrm{d}}$ & $0.03^{\mathrm{d}}$ \\
Corn cob & $1.53^{\mathrm{c}}$ & $150.90^{\mathrm{c}}$ & $0.23^{\mathrm{c}}$ \\
Barley bagasse & $2.73^{\mathrm{c}}$ & $231.96^{\mathrm{c}}$ & $0.35^{\mathrm{c}}$ \\
Pineapple Wreath & $5.80^{\mathrm{b}}$ & $583.63^{\mathrm{b}}$ & $0.90^{\mathrm{b}}$ \\
Corn husk & $12.57^{\mathrm{a}}$ & $1306.94^{\mathrm{a}}$ & $2.00^{\mathrm{a}}$ \\
\hline
\end{tabular}

Note: Equal letters are not differentiated by the $5 \%$ Scott-Knott test. 
In the present study, corn cob was not able to induce expressive results for production xylanase, however, corn straw showed potential for such purpose. Several factors are involved in the enzymatic production process, such as the composition of the medium, carbon source, $\mathrm{pH}$ value, temperature, presence of inducers or additives, aeration and growth time, these variables are considered of essential importance for the development of bioprocesses, because the increase in productivity is directly related to the optimization of the environment and the conditions of the entire production process $[19,20]$. Agroindustrial residues stand out as ideal substrates due to their organic richness, lower cost and being widely available, in addition to having a lower environmental impact when compared to pure substrates [21].

Thus, the choice of substrate is of great importance to obtain a high production of the xylanase. Therefore, corn straw was selected for the next step, due to its great ability to induce high amounts of the enzyme, being easy to obtain and having a low cost.

\subsection{Plackett \& burman}

The next stage of the work consisted of conducting screening to determine the best chemical composition of the culture medium for xylanase production to investigate the influence of $\mathrm{KH}_{2} \mathrm{PO}_{4},\left(\mathrm{NH}_{4}\right)_{2} \mathrm{SO}_{4}$, urea, $\mathrm{MgSO}_{4} .7 \mathrm{H}_{2} \mathrm{O}, \mathrm{CaCl}_{2}$, meat peptone; yeast extract and Tween 80 in the production of the xylanase by $F$. oxysporum. The enzymatic activity values of such design are shows in Table 2. The significant independent variables $(\mathrm{p}<0.05)$ in inducing the production of the xylanase, under submerged conditions, $30{ }^{\circ} \mathrm{C}$ at $180 \mathrm{rpm}$ are presented in the Pareto chart (Figure 1).

Table 2 - Codified variables and real values of the Plackett \& Burman design for the composition of the culture medium for xylanase production.

\begin{tabular}{cccccccccc}
\hline Run & $\begin{array}{c}\mathbf{K H}_{2} \mathbf{P O} \\
(\mathbf{g} / \mathbf{L})\end{array}$ & $\begin{array}{c}\left(\mathbf{N H}_{4}\right) \mathbf{2 S O} \\
(\mathbf{g} / \mathbf{L})\end{array}$ & $\begin{array}{c}\mathbf{U r e a} \\
(\mathbf{g} / \mathbf{L})\end{array}$ & $\begin{array}{c}\mathbf{M g S O}_{4} .7 \mathbf{H}_{2} \mathbf{O} \\
(\mathbf{g} / \mathbf{L})\end{array}$ & $\begin{array}{c}\mathbf{C a C l}_{2} \\
(\mathbf{g} / \mathbf{L})\end{array}$ & $\begin{array}{c}\text { Peptone } \\
(\mathbf{g} / \mathbf{L})\end{array}$ & $\begin{array}{c}\text { Yeast } \\
\mathbf{E x t r a c t} \\
(\mathbf{g} / \mathbf{L})\end{array}$ & $\begin{array}{c}\text { Tween } \\
\mathbf{8 0} \\
(\mathbf{g} / \mathbf{L})\end{array}$ & $\begin{array}{c}\text { Xylanase } \\
\mathbf{a c t i v i t y} \\
\left(\mathbf{U m L} \mathbf{L}^{-1}\right)\end{array}$ \\
\hline 7 & $-1(0)$ & $1(2.8)$ & $1(0.6)$ & $1(0.6)$ & $-1(0)$ & $1(1.5)$ & $1(0.5)$ & $-1(0)$ & 5.65 \\
$13(\mathrm{C})$ & $0(2)$ & $0(1.4)$ & $0(0.3)$ & $0(0.3)$ & $0(0.3)$ & $0(0.75)$ & $0(0.25)$ & $0(0.2)$ & 41.40 \\
$15(\mathrm{C})$ & $0(2)$ & $0(1.4)$ & $0(0.3)$ & $0(0.3)$ & $0(0.3)$ & $0(0.75)$ & $0(0.25)$ & $0(0.2)$ & 43.01 \\
8 & $-1(0)$ & $-1(0)$ & $1(0.6)$ & $1(0.6)$ & $1(0.6)$ & $-1(0)$ & $1(0.5)$ & $1(0.4)$ & 12.94 \\
11 & $-1(0)$ & $1(2.8)$ & $-1(0)$ & $-1(0)$ & $-1(0)$ & $1(1.5)$ & $1(0.5)$ & $1(0.4)$ & 4.00 \\
1 & $1(4)$ & $-1(0)$ & $1(0.6)$ & $-1(0)$ & $-1(0)$ & $-1(0)$ & $1(0.5)$ & $1(0.4)$ & 40.45 \\
5 & $1(4)$ & $1(2.8)$ & $-1(0)$ & $1(0.6)$ & $1(0.6)$ & $-1(0)$ & $1(0.5)$ & $-1(0)$ & 4.10 \\
9 & $-1(0)$ & $-1(0)$ & $-1(0)$ & $1(0.6)$ & $1(0.6)$ & $1(1.5)$ & $-1(0)$ & $1(0.4)$ & 0.73 \\
3 & $-1(0)$ & $1(2.8)$ & $1(0.6)$ & $-1(0)$ & $1(0.6)$ & $-1(0)$ & $-1(0)$ & $-1(0)$ & 29.40 \\
4 & $1(4)$ & $-1(0)$ & $1(0.6)$ & $1(0.6)$ & $-1(0)$ & $1(1.5)$ & $-1(0)$ & $-1(0)$ & 31.34 \\
12 & $-1(0)$ & $-1(0)$ & $-1(0)$ & $-1(0)$ & $-1(0)$ & $-1(0)$ & $-1(0)$ & $-1(0)$ & 7.84 \\
10 & $1(4)$ & $-1(0)$ & $-1(0)$ & $-1(0)$ & $1(0.6)$ & $1(1.5)$ & $1(0.5)$ & $-1(0)$ & 2.73 \\
6 & $1(4)$ & $1(2.8)$ & $1(0.6)$ & $-1(0)$ & $1(0.6)$ & $1(1.5)$ & $-1(0)$ & $1(0.4)$ & 29.70 \\
2 & $1(4)$ & $1(2.8)$ & $-1(0)$ & $1(0.6)$ & $-1(0)$ & $-1(0)$ & $-1(0)$ & $1(0.4)$ & 5.32 \\
$14(\mathrm{C})$ & $0(2)$ & $0(1.4)$ & $0(0.3)$ & $0(0.3)$ & $0(0.3)$ & $0(0.75)$ & $0(0.25)$ & $0(0.2)$ & 41.40 \\
\hline
\end{tabular}

Independent variables encoded outside parentheses and real independent variables inside parentheses. Nota: $\mathrm{C}$ - the central point.

As can be seen, the variables that were significant were urea and $\mathrm{MgSO}_{4} .7 \mathrm{H}_{2} \mathrm{O}$, where the first one had a positive effect, that is, the increase in the amount of this nitrogen source can increase the enzyme's productivity. On the other hand, the second had a negative effect, that is, the smaller the amount of salt used in the medium, the better for enzymatic activity. Thus, these variables were selected to be evaluated in the subsequent step, and the other variables that were not 
significant in the process were kept according to the basal medium proposed by Mandel and Weber (1969) [12]. According to the results, it is possible to see that the concentrations of nutrients in a medium significantly interfere in the production of xylanase. Each microorganism has its own nutritional requirement, being able to use macronutrients such as carbon, hydrogen, oxygen, phosphorus, potassium, nitrogen, sulfur, calcium and magnesium and micronutrients or trace elements such as iron, manganese, cobalt, copper and zinc, secreting a variety of different metabolites in their environment $[3,22]$.

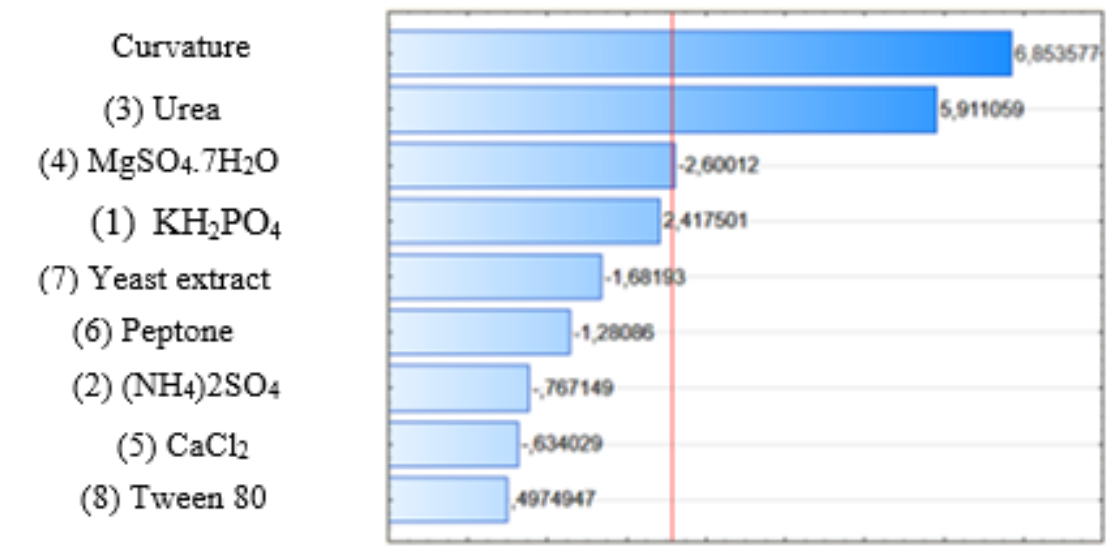

Figure 1 - Pareto chart of the effects of independent variables on the response variable xylanase enzyme activity. $(p=0.05)$.

In the present study, several macronutrients had their concentrations studied, but that of micronutrients remained fixed since the amount of these trace elements was already proposed by Mandel and Weber (1969) [12] as being essential in secondary metabolism, for enzyme production to occur, as they are enzyme activators [3]. Some of these salts also stand out for being important cofactors for enzymes, which in turn can stimulate enzyme production, stabilizing their molecular structure or inhibiting them. As an example, there is potassium phosphate, responsible for the buffering of the medium, and $\mathrm{MgSO}_{4}$, which in the present work inhibited the production of the xylanase enzyme.

Although Tween 80 has not shown a significant effect, it is of great importance for enzyme production, as it facilitates access of the enzyme to the substrate, can increase thermal stability and positive interactions between substrates and enzymes, which justifies its use [23].

\subsection{Composite central rotational desigh (CCRD)}

The last step of the present study consisted of the CCRD experimental design, which is an important tool to determine the level of constituents in the medium and their interaction. Based on the results of Plackett \& Burman, the variables urea and $\mathrm{MgSO}_{4}$ were used to assess their effects on the production of xylanase. The enzymatic activity values can be seen in Table 3 .

The results presented in Table 3 showed that the concentrations of each factor it is noted that the highest enzymatic activity was obtained in assay $2(26.6 \mathrm{U} / \mathrm{mL})$, with high a yield $\left(\mathrm{Y}_{\mathrm{p} / \mathrm{s}}\right)$ and productivity $\left(\mathrm{P}_{\mathrm{p}}\right)$, in which the amount of $\mathrm{MgSO}_{4}$ used in the culture medium is greater than the amount of urea. Furthermore, it can be seen that in the central points and in tests, where the amount of urea was greater than the amount of $\mathrm{MgSO}_{4}$, it was observed lower values of enzymatic activity. 
Table 3 - Values of xylanase enzymatic activities using the DCCR experimental design.

\begin{tabular}{lccc}
\hline Run & $\begin{array}{c}\text { Urea } \\
(\mathbf{g} / \mathbf{L})\end{array}$ & $\begin{array}{c}\mathbf{M g S O}_{4} . \mathbf{7 H} \mathbf{H}_{\mathbf{2}} \mathbf{O} \\
(\mathbf{g} / \mathbf{L})\end{array}$ & $\begin{array}{c}\text { Enzyme activity } \\
\left(\mathbf{U . m L}^{-1}\right)\end{array}$ \\
\hline 2 & $-1(0.70)$ & $1(1.16)$ & 26.60 \\
$10(\mathrm{C})$ & $0(1.67)$ & $0(0.68)$ & 8.21 \\
4 & $1(2.64)$ & $1(1.16)$ & 7.23 \\
1 & $-1(0.70)$ & $-1(0.20)$ & 15.80 \\
7 & $0(1.67)$ & $-1.41(0)$ & 8.30 \\
$12(\mathrm{C})$ & $0(1.67)$ & $0(0.68)$ & 8.21 \\
6 & $1,41(3.04)$ & $0(0.68)$ & 8.80 \\
$9(\mathrm{C})$ & $0(1.67)$ & $0(0.68)$ & 7.10 \\
5 & $-1,41(0.30)$ & $0(0.68)$ & 12.11 \\
$11(\mathrm{C})$ & $0(1.67)$ & $0(0.68)$ & 8.90 \\
$13(\mathrm{C})$ & $0(1.67)$ & $0(0.68)$ & 7.64 \\
8 & $0(1.67)$ & $1.41(1.37)$ & 18.00 \\
3 & $1(2.64)$ & $-1(0.20)$ & 9.84 \\
\hline
\end{tabular}

Growing conditions: 132 hours, $30{ }^{\circ} \mathrm{C}$ and $180 \mathrm{rpm}$. Nota: $\mathrm{C}-$ central point.

In order to estimate the effects of each compound, and confirm the better influence of urea and $\mathrm{MgSO}_{4}$, already seen through the absolute values, the data in Table 3 were analyzed using the Statistica software, whose effects are shown in Table 4. Note that the factor corresponding to the linear effect of the urea variable had a negative effect, while the factor corresponding to the quadratic effect of the $\mathrm{MgSO}_{4}$ variable had a positive effect. Such effects were significant, at the $5 \%$ level, in the induction of enzyme production, under submerged conditions, $30{ }^{\circ} \mathrm{C}$ at $180 \mathrm{rpm}$.

Table 4 - Main effects of the chosen independent variables on xylanase production using the DCCR experimental design.

\begin{tabular}{ccccccc}
\hline Factors & $\mathbf{R}^{\mathbf{2}}$ & $\mathbf{R}^{\mathbf{2}}$ adj. & $\mathbf{E f f e c t}$ & Error & $\mathbf{T}$ & $\mathbf{P}$ \\
\hline $\mathbf{( 1 )}$ Urea $(\mathbf{L})$ & & & $\mathbf{- 7 , 4 9 9}$ & $\mathbf{2 , 3 4 9}$ & $\mathbf{- 3 , 1 9 2}$ & $\mathbf{0 , 0 1 5}$ \\
Urea $(\mathrm{Q})$ & & & 3,981 & 2,519 & 1,580 & 0,158 \\
$(2) \mathrm{MgSO}_{4}(\mathrm{~L})$ & 0,802 & 0,659 & 5,473 & 2,349 & 2,329 & 0,052 \\
$\mathbf{M g S O}_{\mathbf{4}}(\mathbf{Q})$ & & & $\mathbf{6 , 6 6 4}$ & $\mathbf{2 , 5 1 9}$ & $\mathbf{2 , 6 4 5}$ & $\mathbf{0 , 0 3 3}$ \\
1L by 2L & & & $-6,706$ & 3,322 & $-2,019$ & 0,083 \\
\hline
\end{tabular}

The regression model obtained to predict the enzymatic activity of xylanase as a function of urea (X1) and $\mathrm{MgSO}_{4}(\mathrm{X} 2)$ are represented by Equation 4, which predicts that the maximum activity according to the proposed CCRD is $34,523 \mathrm{U} / \mathrm{mL}$. The reparametrized model contains only the statistically significant terms, with a confidence level of $95 \%$, and represents the mathematical equation for optimal production of the enzyme

$$
\text { Xylanase }(U / m L)=7,999-3,749 X_{1}+3,332 X_{2}^{2}
$$

From the results of the analysis of variance (ANAVA), the calculated $\mathrm{F}$ value for xylanase was 44.820 , being greater than and the tabulated $\mathrm{F}$ value $(2: 10=4.103)(\mathrm{p}<0.05)$, in the range of $95 \%$ reliable. Thus, the model can be considered statistically significant, according to the $\mathrm{F}$ test. In addition, the model presented a good coefficient of determination $\left(\mathrm{R}^{2}=0.802\right)$, demonstrating that the closer to 1, the greater the agreement between the experimental results and the theoretical values predicted by the equation. Only $34 \%$ of the observed results were not fitted to the model $\left(\mathrm{R}^{2}=0.659\right)$. To illustrate the effects of independent variables on xylanase production, a response surface graph (Figure 2) was made, generated from the quadratic mathematical model, which presented an optimal point at the lowest urea concentrations and highest concentrations of magnesium sulfate. 


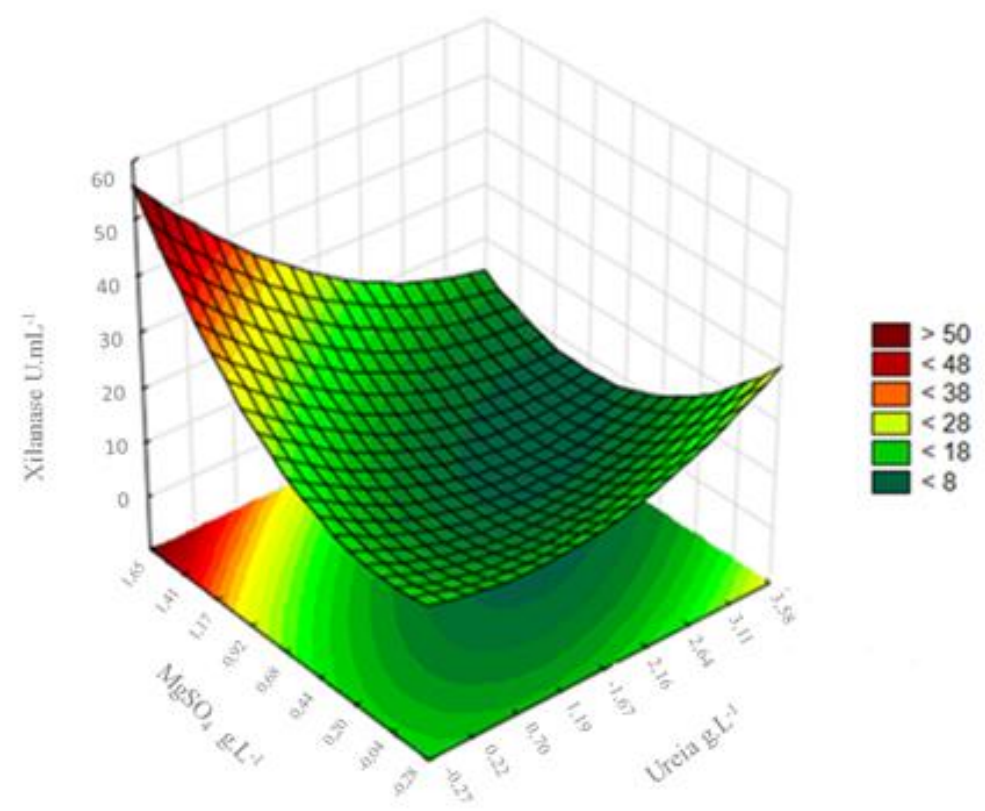

Figure 2 - Response surface for xylanase production influenced by the interaction between Urea and $\mathrm{MgSO} 4$.

Interesting reports on the interaction of magnesium sulfate and/or urea with the production of xylanase, seen in the present study, are also shown in other works. Cui and Zhao (2012) [24] carried out an optimization of the xylanase production from Penicillium sp.WX-Z and found that the enzyme production could be increased to $44 \mathrm{U} / \mathrm{mL}$, when it increases the amount of $\mathrm{MgSO}_{4}$, in addition, the authors stated that $\mathrm{Mg}^{2+}$ may have has a positive effect on the stabilization of the ribosome and cell membranes. When $\mathrm{Mg}^{2+}$ is combined with $\mathrm{Fe}^{2+}$ it plays an important role in xylanase production by Streptomyces sp. and when combined with $\mathrm{Zn}^{2+}$ and $\mathrm{Fe}^{2+}$ it can stimulate xylanase production by Streptomyces thermodiasticus.

\section{CONCLUSION}

The results obtained in this work demonstrated that corn straw, as a carbon source, is effective for the production of xylanase. In addition, it is a low-cost and sustainable source, being of paramount importance to minimize the cost of the enzyme and make the hydrolysis step cheaper, which is the most costly step in the biofuel production process. The Plackett-Burman experimental design helped to select the variables that significantly influenced the production of the enzyme, selecting urea and magnesium sulfate as the components with a significant effect on the production of xylanase. CCRD planning contributed to adjusting the culture medium requirements for the production of xylanase. Furthermore, the absolute activity obtained was equal to $26.57 \mathrm{U} / \mathrm{mL}$ and the maximum activity predicted by the CCRD was equal to $34.52 \mathrm{U} / \mathrm{mL}$. The present work is of great importance, as it evaluated corn straw as being excellent for the production of xylanase from $F$. oxysporum, under submerged conditions, together with the concentrations of urea and magnesium sulfate, which is unprecedented.

\section{REFERENCES}

1. Gelfand I, Sahajpal R, Zhang X, Izaurralde RC, Gross KL, Robertson GP. Sustainable bioenergy production from marginal lands in the US Midwest. Nature. 2013;493(7433):514-17. doi: 10.1038/nature11811

2. Glass NL, Schmoll M, Cate JH, Coradetti S. Plant cell wall deconstruction by ascomycete fungi. Ann Rev Microbiol. 2013 Jun;67:477-98. doi: 10.1146/annurev-micro-092611-150044 
3. Uday USP, Choudhury P, Bandyopadhyay P, Bhunia B. Classification, mode of action and production strategy of xylanase and its application for biofuel production from water hyacinth. Int J Biol Macromolecules. 2015 Oct;82:1-14. doi: 10.1016/j.ijbiomac.2015.10.086

4. Heinen PR, Henn C, Peralta RM, Bracht A, Simão, RDCG, da Conceição Silva JL, et al. Xylanase from Fusarium heterosporum: Properties and influence of thiol compounds on xylanase activity. African $\mathrm{J}$ Biotechnol. 2014 Feb;13(9):1047-55. doi: 10.5897/AJB2013.13282

5. Lombard L, Sandoval-Denis M, Lamprecht SC, Crous PW. Epitypification of Fusarium oxysporumclearing the taxonomic chaos. Persoonia. 2019 Dec;43:1-47. doi: 10.3767/persoonia.2019.43.01

6. Pokhrel S, Joo JC, Yoo YJ. Shifting the optimum $\mathrm{pH}$ of Bacillus circulans xylanase towards acidic side by introducing arginine. Biotechnol Bioproc Engin. 2013 July;18:35-42. doi: 10.1007/s12257-0120455-x

7. Irfan M, Asghar U, Nadeem M, Nelofer R, Syed Q. Optimization of process parameters for xylanase production by Bacillus sp. in submerged fermentation. J Radiation Res Applied Sciences. 2015 Nov;10(9):1-9. doi: 10.1016/j.jrras.2015.10.008

8. Kallel F, Driss D, Chaari F, Zouari-Ellouzi S, Chaabouni M, Ghorbel R, et al. Statistical optimization of low-cost production of an acidic xylanase by Bacillus mojavensis UEB-FK: its potential applications. Biocatalysis and Agricultural Biotechnol. 2016 Nov;5:1-10. doi: 10.1016/j.bcab.2015.11.005

9. Araújo WL, Lima AOS, Azevedo JL, Marcon J, Sobral JK, Lacava PT. Manual: isolamento de microrganismos endofiticos. Piracicaba (SP): CALG; 2002.

10. Figueiredo MB. Estudos sobre a aplicação do método de Castellani para conservação de fungos patógenos em plantas. O Biológico. 1967;33(1):9-13.

11. Vogel HJA. Convenient growth medium for Neurospora crassa (medium N). Microbiol Genetic Bulletim. 1956;13:42-3.

12. Mandels M, Weber J. The production of cellulases. Adv Chem Series. 1969;95:391-414. doi: 10.1016/B978-0-12-040305-9.50006-6

13. Miller GL. Use of dinitrosalicylic acid reagent for determination of reducing sugar. Analytical chemistry. 1959;31(3):426-8.

14. Plackett RL, Burman JP. The design of optimum multifactorial experiments. Biometrika. 1946 Jun;33(4):305-25. doi: 10.2307/2332195

15. Senthilkumar SR, Ashokkumar B, Raj KC, Gunasekaran P. Optimization of medium composition for alkali-stable xylanase production by Aspergillus fischeri Fxn 1 in solid-state fermentation using central composite rotary design. Bioresource Technology. 2005 Jan;96(12):1380-6. doi: 10.1016/j.biortech.2004.11.005

16. Pritsch RK, Nascimento AGLC, Bittencourt JWF, Rasbold LM, da Conceição Silva JL, Maller A, et al. Avaliação da atividade xilanase de cultivos de fungos mesófilo e termófilo utilizando resíduos e subprodutos agrícolas. Braz J Development. 2020 Aug;6(8):61349-56. doi: 10.34117/bjdv6n8-524

17. Bhardwaj N, Kumar B, Verma PA. Detailed overview of xylanases: an emerging biomolecule for current and future prospective. Bioresour Bioprocess. 2019 Oct;6:40. doi: 10.1186/s40643-019-0276-2

18. Sepahy AA, Ghazi S, Akhavan SM. Cost-effective production and optimization of alkaline xylanase by indigenous Bacillus mojavensis AG137 fermented on agricultural waste. Enzyme Research. 2011 Jun;2011:593624. doi: 10.4061/2011/593624

19. Sivakumar T, Thangamathi P, Mariashobana A, Rathimeena T, Shankar T. Optimization of Invertase production using Saccharomyces cerevisiae MTCC 170 under varying cultural conditions. J Adv Med Life Sci. 2014 Mar;1(2):1-8.

20. Rigo D, Gayeski L, Tres GA, Camera FD, Zeni J, Valduga E, et al. Produção microbiológica de enzimas: uma revisão. Braz J Development. 2021 Jan;7(1):9232-54. doi: 10.34117/bjdv7n1-624

21. Salazar LN, Dal Maso SS, Ogimbosvski TA, Daronch NA, Zeni J, Valduga E, et al. Production, partial characterization and application of cellulases by newly isolated Penicillium sp. using agro-industrial substrate solid-state fermentation. Industrial Biotechnol. 2019 Apr;15(2):79-88. doi: 10.1089/ind.2018.0029.

22. Kumar L, Kumar D, Nagar S, Gupta R, Garg N, Kuhad RC, et al. Modulation of xylanase production from alkaliphilic Bacillus pumilusVLK-1 through process optimization and temperature shift operation. Biotech. 2014 Aug;4:345-56. doi: 10.1007/s13205-013-0160-2

23. Xin D, Yang M, Chen X, Zhang Y, Ma L, Zhang J. Improving the hydrolytic action of cellulases by Tween 80: compensating for lost cellobiohydrolase activity Cel7A. ACS Sustainable Chem Eng. 2017 Oct;5(12):11339-45. doi: 10.1021/acssuschemeng.7b02361

24. Cui F, Zhao L. Optimization of xylanase production from Penicillium sp. WX-Z1 by a two-step statistical strategy: plackett-burman and box-behnken experimental design. Int J Mo Sci. 2012 Aug;13(8):10630-46. doi: 10.3390/ijms130810630 